\title{
DEFINIÇÃO DE PROPRIEDADE PARA FINS DE PAGAMENTO DO IPTU - IMPOSTO SOBRE A PROPRIEDADE PREDIAL E TERRITORIAL URBANA
}

\section{DEFINITION OF PROPERTY FOR THE PURPOSE OF PAYMENT OF MUNICIPAL REAL ESTATE TAX}

\author{
Julcira Maria de Mello Vianna Lisboa
}

\begin{abstract}
Doutora em Direito pela PUC-SP. Professora assistente-doutora da PUC-SP, coordenadora do Departamento IV da PUC-SP, coordenadora do curso de graduação da PUC-SP. E-mail: julcira@ hotmail.com
\end{abstract}

\begin{abstract}
RESUMO: O presente trabalho trata de forma breve e pontual sobre a propriedade para fins de pagamento de IPTU. O objetivo é elucidar alguns pontos sobre essa matéria a fim de clarear a visão a respeito da importância do Imposto sobre a Propriedade Predial e Territorial Urbana. Para isso, a investigação se dá por meio do método dedutivo, definindo-se, num primeiro momento, a propriedade e sua função social e seu direcionamento para o bem da coletividade e o interesse social. Num segundo momento, verifica-se o imóvel por acessão física e imóvel por natureza e na sequência os vários critérios que podem ser utilizados para identificar e diferenciar o espaço rural do urbano. Por fim, analisam-se os aspectos da hipótese de incidência do IPTU e as alíquotas progressivas com caráter fiscal de abastecimento dos cofres públicos.
\end{abstract}

Palavras-chave: Propriedade. Função social. Imposto sobre a propriedade predial e territorial urbana. IPTU.

\begin{abstract}
This paper aims to deal in a brief and timely manner on the definition of property for the purpose of payment of municipal real estate tax. The goal is to elucidate some points on the subject in order to clear the vision on the importance of the municipal real estate tax. For this reason, this research shall be conducted through the deductive method, defining, at first, the property and its social function and its direction for the good of the community and social interest. Secondly, there is the property by physical accession and still by nature and following the various criteria that can be used to identify and differentiate the rural areas of the city. Finally, we analyze aspects of the hypothesis of incidence of the municipal real estate tax and progressive tax rates with tax character of supply from public safes.
\end{abstract}

Keywords: Property. Social function. Municipal real estate tax. IPTU.

SUMÁRIO: Introdução; 1 Definição de propriedade; 1.1 Domínio útil; 1.2 Posse; 2 Imóvel por acessão física e imóvel por natureza; 2.1 Imóvel por acessão física ou natural; 2.2 Imóvel por Natureza; 3 Zona Urbana e Zona Rural; 4 Aspectos da Hipótese de Incidência do IPTU; 4.1 Aspecto ou Critério Pessoal; 4.1.1 Sujeito Ativo; 4.1.2 Sujeito Passivo; 4.1.3 Responsável Tributário; 4.2 Aspecto Temporal; 4.3 Aspecto Espacial; 4.4 Aspecto Material; 4.4.1 Base de Cálculo; 4.4.2 Alíquota; Conclusão; Referências. 


\section{INTRODUÇÃO}

O IPTU (Imposto sobre a Propriedade Predial e Territorial Urbana) está previsto na Constituição Federal, artigo 156, inciso I. O Código Tributário Nacional trata do imposto nos artigos 32,33 e $34^{1}$.

A competência para instituí-lo pertence aos Municípios (art. 156, I, CF), ao Distrito Federal e até pela União, caso haja territórios sem divisão de Municípios, por força do artigo 147da Constituição Federal. Tais entes políticos devem criar o imposto através de Lei Ordinária municipal ou distrital ou Lei Ordinária federal, dependendo de quem a editar. Tal norma trará seus elementos essenciais, ou seja, sua regra-matriz de incidência, com seus critérios material, territorial, espacial, subjetivo (indicação dos sujeitos) e quantitativo (indicação da base de cálculo e da alíquota). O fato gerador do IPTU, nos termos do artigo 32 do CTN, será "a propriedade, o domínio útil ou a posse de bem imóvel, por natureza ou por acessão física, definido na lei civil, localizado na zona urbana do Município". Portanto, o fato imponível do imposto, representado por um verbo mais complemento é ser proprietário de imóvel localizado na zona urbana do Município.

\section{DEFINIÇÃO DE PROPRIEDADE}

A propriedade vem a ser o direito que determinada pessoa, seja física ou jurídica, tem de possuir, usar, gozar ou dispor de um bem ou readquiri-lo, nos termos da lei, de quem, de forma injusta o possua ou o detenha. Cumpre dizer ainda que a propriedade deve cumprir sua função social, princípio de ordem pública, ou seja, deve ela ser direcionada visando o bem da coletividade, o interesse social.

O Código Civil trata da matéria no artigo 1228.

Maria Helena Diniz ${ }^{2}$, a respeito da propriedade, diz ser "o direito que a pessoa física ou jurídica tem, dentro dos limites normativos, de usar, gozar, dispor de um bem corpóreo ou incorpóreo, bem como reivindicá-lo de quem injustamente o detenha".

Orlando Gomes ${ }^{3}$, entende propriedade como um direito que apresenta diversos aspectos, sendo sua definição complexa, absoluta, perpétua e exclusiva. Para tanto utiliza três critérios, o sintético, o analítico e o descritivo.

\footnotetext{
${ }^{1}$ Art. 32. O imposto, de competência dos Municípios, sobre a propriedade predial e territorial urbana tem como fato gerador a propriedade, o domínio útil ou a posse de bem imóvel por natureza ou por acessão física, como definido na lei civil, localizado na zona urbana do Município.

$\S 1^{\circ}$ Para os efeitos deste imposto, entende-se como zona urbana a definida em lei municipal; observado o requisito mínimo da existência de melhoramentos indicados em pelo menos 2 (dois) dos incisos seguintes, construídos ou mantidos pelo Poder Público:

I - meio-fio ou calçamento, com canalização de águas pluviais;

II - abastecimento de água;

III - sistema de esgotos sanitários;

IV - rede de iluminação pública, com ou sem posteamento para distribuição domiciliar;

V - escola primária ou posto de saúde a uma distância máxima de 3 (três) quilômetros do imóvel considerado.

$\S 2^{\circ}$ A lei municipal pode considerar urbanas as áreas urbanizáveis, ou de expansão urbana, constantes de loteamentos aprovados pelos órgãos competentes, destinados à habitação, à indústria ou ao comércio, mesmo que localizados fora das zonas definidas nos termos do parágrafo anterior.

Art. 33. A base do cálculo do imposto é o valor venal do imóvel.

Parágrafo único. Na determinação da base de cálculo, não se considera o valor dos bens móveis mantidos, em caráter permanente ou temporário, no imóvel, para efeito de sua utilização, exploração, aformoseamento ou comodidade.

Art. 34. Contribuinte do imposto é o proprietário do imóvel, o titular do seu domínio útil, ou o seu possuidor a qualquer título.

${ }^{2}$ DINIZ, Maria Helena. Curso de Direito Civil Brasileiro - Direito das Coisas. Vol. 4. 24. ed. São Paulo: Saraiva, 2009 , p. 114.

3 "O sintético, o analítico e o descritivo. Sinteticamente, é de se defini-lo com Windscheid, como a submissão de uma coisa, em todas as suas relações, a uma pessoa. Analiticamente, o direito de usar, fruir e dispor de um bem, e de reavê-lo de quem injustamente o possua. Descritivamente, o direito complexo, absoluto perpétuo e exclusivo, pelo qual uma coisa fica submetida à
}

Revista de Direito Brasileira | São Paulo, SP | v. 14 | n. 6 | p. 51- 64 | maio/ago. 2016 
A Constituição Federal trata a propriedade como direito fundamental além de esclarecer que ela deve atender à sua função social ${ }^{4}$. Assim todo o direito de usar, gozar, dispor ou até readquirir deve ser entendido dentro dos limites e parâmetros legais, respeitando a função social da propriedade.

Portanto, o detentor da propriedade tem a obrigação de direcioná-la, atendendo sua função social, ou seja, deve gozar e dispor dela, obedecendo as limitações impostas pela lei condicionado que fica a uma finalidade de ordem social, garantindo o bem-estar da coletividade e servindo de instrumento para a realização de valores consagrados pela Constituição. Esse objetivo é obtido através de leis que impõem obrigações, deveres, responsabilidades e limites, atendendo aos interesses sociais.

Elizabeth Nazar Carrazza ${ }^{5}$ aduz:

A Constituição Federal em vigor, numa clara demonstração de sua preocupação com o social, ao mesmo tempo em que garante o direito de propriedade - como já salientado no capítulo referente à proibição do confisco - exige que ela esteja voltada para o atendimento de uma função social.

A respeito do tema José Eduardo Soares de Melo ${ }^{6}$ :

Entretanto, como a propriedade deve atender à sua função social (art. $5^{\circ}$, XXII e XXIII; art. 170, III, arts. 184 e 186 daCF), o exercício do seu direito deve estar em consonância com a suas finalidades econômicas e sociais, preservando a flora, a fauna, as belezas naturais, o equilíbrio ecológico e o patrimônio histórico e artístico, evitando a poluição do ar e das águas (art. $1228 \S 1^{\circ}$ do Código Civil). Os objetivos da função social podem ser alcançados mediante obrigações positivas (proprietário construir em terreno ocioso), e como regras impeditivas de ações (proibição de edificações, visando funções do urbanismo; ordenamento do crescimento de atividades, segregação de indústrias insalubres, conveniente uso de ocupação do solo, evitando especulação imobiliária).

Jorge Miranda ${ }^{7}$ esclarece sobre o tema:

Há uma garantia institucional da propriedade no sentido de que seria inconstitucional a lei ordinária reduzir os direitos das pessoas sobre as coisas ao usufruto ou a outros direitos reais menores; a lei civil tem de conter um direito de propriedade com o feixe de poderes de uso, fruição e disposição que lhe são inerentes na tradição jurídica e cultural no nosso país.

Em suma, a Constituição conceitua propriedade de forma implícita, adotando um sentido largo e elástico ao termo, abrangendo o domínio útil e a posse como exteriorização da propriedade.

$$
\text { Nesse sentido Aires Barreto }{ }^{8} \text { explica: }
$$

vontade de uma pessoa, com as limitações da lei” (GOMES, Orlando. Direitos Reais. 19 ed. Rio de Janeiro: Forense, 2005, p. 126).

${ }^{4}$ Artigo $5^{\circ}$ incisos XXII e XXIII da CF.

${ }^{5}$ CARRAZZA, Elizabeth Nazar. IPTU e Progressividade, Igualdade e Capacidade Contributiva. 2. ed. São Paulo: QuartierLatin, 2015, p. 190.

${ }^{6}$ MELO, José Eduardo Soares de. Curso de Direito Tributário. 9. ed. São Paulo:Dialética, 2010, p. 543.

${ }^{7}$ MIRANDA, Jorge. Manual de Direito Constitucional. Tomo IV. 3. Ed. Lisboa: Coimbra Editora, 2000, p. 527.

${ }^{8}$ BARRETO, Aires F. Imposto Predial e Territorial Urbano - IPTU. In: Ives Gandra da Silva Martins (coord.). Curso de Direito Tributário. 12. ed. São Paulo: Saraiva, 2010, p. 948.

Revista de Direito Brasileira | São Paulo, SP | v. 14 | n. 6 | p. 51- 64 | maio/ago. 2016 
O vocábulo "propriedade" não foi utilizado pela Constituição em sentido técnico. O termo foi empregado na sua acepção correntia, comum, vulgar. Tanto isso é certo que, ao garantir o direito de propriedade (art. $5^{\circ}, \mathrm{XXV}$ ), ao afirmar que a propriedade atenderá sua função social (art. $5^{\circ}$, XXIII) ao permitir o uso da propriedade privada pela autoridade pública, no caso de iminente perigo público (art. $5^{\circ}, \mathrm{XXV}$ ), ao vedar que a pequena propriedade rural seja objeto de penhora, em certos casos(art. $5^{\circ}, \mathrm{XXXVI)}$ e de desapropriação para fins de reforma agrária (art. 185 e seu inciso I), seguramente não ousou a Constituição pôr ao largo de tais proteções a enfiteuse, o usufruto, a posse. Certamente não pretendeu que a propriedade deva cumprir sua função social (arts. 182 e 186), mas infensas a esse dever estejam a enfiteuse e a posse. A interpretação sistemática exige que se conclua pela utilização do termo "propriedade" no sentido comum e não no seu significado jurídico.

O Código Tributário Nacional em seu artigo 32 prevê a incidência do imposto sobre a propriedade predial e territorial urbana, tendo como aspecto material da hipótese de incidência, ou seja, como fato gerador, assim denominado pela lei, a propriedade, o domínio útil ou a posse de bem imóvel.

Eis a adoção da definição larga de propriedade, vez que aborda também o domínio útil e a posse. Caso tivéssemos uma interpretação estreita do termo somente os proprietários seriam sujeitos passivos, ou melhor, contribuintes do imposto ${ }^{9}$. Proprietário na acepção restrita seria aquele indivíduo que, nos termos do artigo 1228 do Código Civil é detentor do uso, gozo e disposição do bem, além do domínio direto, adquirido através de Escritura Pública de Compra e Venda devidamente registrada no Cartório de Registro de Imóveis competente, conforme os ditames da lei.

Apenas quando todos os elementos que constituem a propriedade estão presentes, reunidos formando um todo é que estaremos diante da propriedade plena.

\subsection{DOMÍNIO ÚTIL}

Passaremos a definição de domínio útil e posse apenas para nortear o entendimento do tema, sem que nos aprofundemos, em demasiado na matéria. Domínio útil ${ }^{10}$ é considerado como fato ou situação jurídica, que se refere à propriedade, em que o proprietário outorga a outrem os direitos de usar, gozar e dispor do bem ficando apenas com o título.

Aires Barreto esclarece: "Configura-se domínio útil quando o proprietário, despojandose dos poderes de uso, gozo e disposição da coisa, outorga-os a outrem (denominado enfiteuta) reservando-se, tão só, o domínio direto ou eminente" $"$.

Explicando melhor, o domínio útil condiz com os direitos de usar, gozar e dispor do bem. Podemos dar como exemplo a enfiteuse, direito real sobre coisa alheia.

A enfiteuse (também denominada aforamento) deixou de ser regulada pelo Código Civil de 2002. Porém, ainda mencionamos como exemplo, por ter caráter perpétuo, ou melhor, em razão da continuidade daquelas que foram firmadas pelo Código Civil de 1916 até sua extinção.

O enfiteuta, nos termos da lei, adquire através de pagamento combinado entre as partes, o domínio útil do proprietário do imóvel, que poderá usufruir e gozar do bem da maneira que lhe

\footnotetext{
${ }^{9}$ COELHO, Sacha Calmon Navarro. Curso de Direito Tributário Brasileiro. 14. ed. Rio de Janeiro: Forense, 2015 , p. 524.

10 “O domínio útil compreende os direitos de utilização e disposição, inclusive o de alienação, conferidos ao foreiro, relativamente a prédio enfitêutico; contrapondo-se ao "domínio direto (restrito à substância do bem)" (MELO, José Eduardo Soares de. Curso de Direito Tributário. 9. ed. São Paulo: Dialética, 2010, p. 544).

${ }^{11}$ BARRETO, Aires F. Imposto Predial e Territorial Urbano - IPTU. In: Ives Gandra da Silva Martins (coord.). Curso de Direito Tributário. 12. ed. São Paulo: Saraiva, 2010, p. 967.
} 
aprouver. Essa transmissão se restringe ao domínio útil, pois o domínio direto continua com o proprietário $^{12}$. A enfiteuse se transmite com a herança e é passível de alienação.

\subsection{POSSE}

A posse é considerada como exteriorização da propriedade. O Código Civil prevê a posse: "Art. 1.196. Considera-se possuidor todo aquele que tem de fato o exercício, pleno ou não, de algum dos poderes inerentes à propriedade".

Pode-se dizer que configura uma situação de fato, prestigiada pela lei, na qual se encontra determinado indivíduo que, na condição de possuidor deum bem o disponha para si com a intenção de ser dono. O possuidor tem, de alguma maneira, algum dos poderes inerentes à propriedade, e, portanto, a posse é a sua manifestação.

Washington de Barros Monteiro a respeito: "A posse constitui o sinal exterior da propriedade, é o jus possidendi, o direito de possuir, e pelo qual o proprietário, de modo geral, afirma seu poder sobre aquilo que lhe pertence" ${ }^{\text {.13. }}$.

Misabel Derzi ${ }^{14}$, sobre o tema esclarece:

Entendemos que, se se pretende respeitar a Constituição, não se pode tributar qualquer posse. Apenas aquela ad usucapionem, ou que é exteriorização da propriedade. O imposto também não incide sobre a posse a qualquer título, precária ou direta como aquela do arrendatário, locador, ocupante, comodatário, usuário, habitador, detentor ou administrador de bens de terceiro, tais pessoas nunca serão proprietários.

Segundo Rosa Maria de Andrade Nery e Nelson Nery Junior ${ }^{15}$ :

Posse ad usucapionem é aquela que enseja aquisição da propriedade por meio de usucapião. Não é mera detenção. Não é posse exercida em nome de outrem. É posse de quem tem a coisa como sua e se apresenta como se fosse dono, ou seja, com animus domini.

Portanto, não é qualquer posse que possibilita a cobrança do imposto em questão, mas sim aquela em que o possuidor tenha animus domini, ou seja, intenção de agir como dono ou de ser dono, que é passível da imposição tributária.

\section{IMÓVEL POR ACESSÃO FÍSICA E IMÓVEL POR NATUREZA}

\subsection{IMÓVEL POR ACESSÃO FÍSICA OU NATURAL}

O imóvel por acessão física representa tudo que se une ou adere ao imóvel por acessão, que é modo legal de adquirir a propriedade, onde tudo o que se incorpora, por força da natureza fica dela fazendo parte. Podem ocorrer por formação de ilhas, por aluvião, por avulsão, por abandono de álveo, pelas sementes lançadas a terra e por construções, desde que não se possa extrair sem que se destrua ou se modifique.

\footnotetext{
12 "Mas, é evidente, a transmissão restringe-se ao domínio útil. A substância, ou domínio direto, remanesce com o proprietário ou senhorio" (RIZZARDO, Arnaldo. Direito das Coisas. 4. ed. Rio de Janeiro: Forense, 2004, p. 848).

${ }^{13}$ MONTEIRO, Washington de Barros. Curso de Direito Civil. 19. Ed. São Paulo: Saraiva, 1979, p. 20.

${ }^{14}$ BALEEIRO, Aliomar. Direito Tributário Brasileiro. 11. ed. Rio de Janeiro: Forense, 2004, p. 237.

${ }^{15}$ JUNIOR, Nelson Nery; NERY, Rosa Maria de Andrade. Código Civil Comentado e Legislação Extravagante. 3. ed. São Paulo: Ed. Revista dos Tribunais, 2005, p. 608.
} 
Bens imóveis por sua natureza: abrange o solo com sua superfície, os seus acessórios e adjacências naturais, compreendendo as árvores e frutos pendentes, o espaço aéreo e o subsolo.

\subsection{IMÓVEL POR NATUREZA}

O imóvel por natureza é aquele que abarca o solo com sua superfície, os seus acessórios, compreendendo as árvores, frutos pendentes, vegetação, o espaço aéreo, o subsolo e tudo aquilo que lhe incorporar naturalmente, sem que haja intervenção do homem.

\section{ZONA URBANA E ZONA RURAL}

É importante que se destaque a diferença de zona urbana e zona rural, tendo em vista que o Imposto sobre a Propriedade Territorial Urbana de competência dos Municípios e do Distrito Federal incide sobre imóveis localizados na zona urbana do Município.

Mas o que é zona urbana? Como diferençá-la da zona rural?

Rural é próprio do campo. É aquela que se destina à exploração agrícola, pecuária, extrativa vegetal ou agroindustrial. Trata-se de região que não foi urbanizada, ou seja, em oposição ao que é próprio da cidade.

Há diversas maneiras de se diferençar o espaço rural do urbano. Há vários critérios que podem ser utilizados para que se possa identificar cada um deles.

O Código Tributário Nacional nos traz a seguinte diretriz em seu artigo $32 \S \S 1^{\circ}$ e $2^{\circ}$ :

$\S 1^{\circ}$ Para os efeitos deste imposto, entende-se como zona urbana a definida em lei municipal, observado o requisito mínimo da existência de melhoramentos indicados em pelo menos 2 (dois) dos incisos seguintes, construídos ou mantidos pelo Poder Público:

I - meio-fio ou calçamento, com canalização de águas pluviais;

II - abastecimento de água;

III - sistema de esgotos sanitários;

IV - rede de iluminação pública, com ou sem posteamento para distribuição domiciliar;

V - escola primária ou posto de saúde a uma distância máxima de 3 (três) quilômetros do imóvel considerado.

$\S 2^{\circ}$ A lei municipal pode considerar urbanas as áreas urbanizáveis, ou de expansão urbana, constantes de loteamentos aprovados pelos órgãos competentes, destinados à habitação, à indústria ou ao comércio, mesmo que localizados fora das zonas definidas nos termos do parágrafo anterior.

Assim pode-se depreender que o CTN utilizou de um critério geográfico, ou seja, de acordo com a localização, para se entender o que é zona urbana, devendo ainda ser definida em lei municipal e conter duas melhorias elencadas nos incisos de $\mathrm{I}$ a $\mathrm{V}$ do $\S 1^{\circ}$ do artigo citado.

Nos termos do $\S 2^{\circ}$ do citado artigo a lei municipal poderá considerar urbanas, para efeito de incidência do IPTU as áreas urbanizáveis ou de expansão urbana desde que constem de loteamentos devidamente aprovados, voltados para a habitação, para a indústria ou para o comércio.

Apesar de o CTN valer-se do critério da localização para a identificação da zona urbana, para fins de incidência do IPTU há entendimento jurisprudencial que utiliza parâmetro diferente.

O STJ tem aplicado a destinação do imóvel como padrão para que se possa diferençar zona urbana de zona rural. 
Eis algumas delas:

TRIBUTÁRIO. IPTU. ITR. FATO GERADOR. IMÓVEL SITUADO NA ZONA URBANA. LOCALIZAÇÃO. DESTINAÇÃO. CTN, ART. 32. DECRETO-LEI N. 57/66. VIGỂNCIA. 1.Ao ser promulgado, o Código Tributário Nacional valeu-se do critério topográfico para delimitar o fato gerador do Imposto sobre a Propriedade Predial e Territorial Urbana (IPTU) e o Imposto sobre a Propriedade Territorial Rural (ITR): se o imóvel estivesse situado na zona urbana, incidiria o IPTU; se na zona rural, incidiria o ITR.2. Antes mesmo da entrada em vigor do CTN, o Decreto-Lei $n^{\circ}$ 57/66 alterou esse critério, estabelecendo estarem sujeitos à incidência do ITR os imóveis situados na zona rural quando utilizados em exploração vegetal, agrícola, pecuária ou agroindustrial. 3. A jurisprudência reconheceu validade ao DL 57/66, o qual, assim como o CTN, passou a ter o status de lei complementar em face da superveniente Constituição de 1967. Assim, o critério topográfico previsto no art. 32 do CTN deve ser analisado em face do comando do art. 15 do DL 57/66, de modo que não incide o IPTU quando o imóvel situado na zona urbana receber quaisquer das destinações previstas 4. Recurso especial provido. (STJ. REsp 492.869/PR, $1^{\text {a }}$ Turma, Rel. Min. Teori Albino Zavascki, DJ de 7.3.2005).

TRIBUTÁRIO. IMÓVEL NA ÁREA URBANA. DESTINAÇÃO RURAL. IPTU. NÃO-INCIDÊNCIA. ART. 15 DO DL 57/1966. RECURSO REPETITIVO. ART. 543-C DO CPC. 1. Não incide IPTU, mas ITR, sobre imóvel localizado na área urbana do Município, desde que comprovadamente utilizado em exploração extrativa, vegetal, agrícola, pecuária ou agroindustrial (art. 15 do DL 57/1966). 2. Recurso Especial provido. Acórdão sujeito ao regime do art. 543-C do CPC e da Resolução 8/2008 do STJ" (G.N., REsp 1.112.646-SP, rel. Min. Herman Benjamin, $1^{\text {a }}$ Seção, j. 26.08.2009, DJ. 28.08.2009).

Apesar das decisões do STJ que concentram o critério da destinação do imóvel com base no DL 57/66, art. 15, cujo STF reconheceu sua validade, entendemos que os Municípios devem por meio de lei ordinária municipal ${ }^{16}$ identificar, zona urbana pelo critério geográfico, apontado na Lei Complementar, artigo $32 \S \mathrm{s} 1^{\circ}$ e $2^{\circ}$ do CTN.

Kiyoshi Harada $^{17}$, a esse respeito:

Aliás, a se adotar o critério da destinação do imóvel impossibilitará ao Município o cumprimento de sua missão de ordenar o pleno desenvolvimento das funções sociais da cidade (art. 182 da $\mathrm{CF}^{18}$ ), pois simplesmente desapareceria a fronteira entre zona rural e urbana.

Utilizar a destinação como critério, nos parece uma situação conflituosa com os próprios interesses urbanísticos do Município. Ainda que por hipótese, como ficaria a situação dos comerciantes, transeuntes, moradores, empresários do centro de São Paulo se lá houvesse uma

\footnotetext{
${ }^{16}$ A esse respeito Roque Carrazza: "Sirva-nos de exemplo, a respeito, a posição doutrinária (dominante) de que "zona urbana", para fins de tributação por meio de imposto predial e territorial urbano (IPTU), é aquela que atende às "especificações" do art. 32 $\S \S 1^{\circ}$ e $2^{\circ}$, do CTN" (CARRAZZA, Roque Antonio, Curso de Direito Constitucional Tributário. 30. ed. São Paulo: Malheiros Editores, 2015, pp. 214/215).

${ }^{17}$ HARADA, Kiyoshi. Direito Financeiro e Tributário. 24. ed. São Paulo: Atlas, 2015, p. 492.

${ }^{18}$ Art. 182. A política de desenvolvimento urbano, executada pelo Poder Público municipal, conforme diretrizes gerais fixadas em lei, tem por objetivo ordenar o pleno desenvolvimento das funções sociais da cidade e garantir o bem-estar de seus habitantes.
} 
área de criação de gado ou de porcos? Salvo melhor juízo, o critério da destinação apontado no artigo 15 do DL 57/66 acaba por afrontar o próprio artigo 182 da CF ao determinar que a política do desenvolvimento urbano tenha como um de seus objetivos garantir o bem-estar de seus habitantes.

\section{ASPECTOS DA HIPÓTESE DE INCIDÊNCIA DO IPTU}

Após verificarmos as linhas gerais sobre o fato que faz nascer a obrigação tributária de pagar IPTU passamos a analisar sua regra-matriz.

\subsection{ASPECTO OU CRITÉRIO PESSOAL}

\subsubsection{SUJEITO ATIVO}

O critério pessoal do IPTU tem como sujeitos ativos os Municípios, nos termos do artigo 156, I da CF ou ainda o Distrito Federal bem como a União, conforme os ditames do artigo 147 da CF.

\subsubsection{SUJEITO PASSIVO}

O contribuinte do imposto é aquele que revela capacidade econômica e está previsto no art. 34 do $\mathrm{CTN}^{19}$ : "Contribuinte do imposto é o proprietário do imóvel, o titular do seu domínio útil, ou o seu possuidor a qualquer título".

O proprietário ou o coproprietário do imóvel é o detentor do domínio direto e da posse, ou seja, aquele que, nos limites legais, tem a faculdade de usar, gozar e dispor da coisa, bem como reivindicá-la de quem injustamente a possua ou a detenha. Em resumo é aquele que tem a posse do imóvel e o domínio direto, adquirido através de Escritura Pública de Compra e Venda devidamente registrada no Cartório de Registro de Imóveis competente, conforme os ditames da lei.

São também contribuintes do IPTU, conforme dispõe o artigo citado, o titular do seu domínio útil, ou o seu possuidor a qualquer título.

O enfiteuta é contribuinte do imposto. Esclarecemos que nos termos do artigo 2.038 do Código Civil a enfiteuse ainda persiste no nosso sistema legislativo até sua extinção, sendo vedadas novas instituições: "Fica proibida a constituição de enfiteuses e subenfiteuses, subordinando-se as existentes, até sua extinção, às disposições do Código Civil anterior, Lei no 3.071, de 1 o de janeiro de 1.916, e leis posteriores".

O artigo 678 do Código Civil de 1.916 prevê a enfiteuse: "Dá-se a enfiteuse, aforamento, ou emprazamento, quando por ato entre vivos, ou de última vontade, o proprietário atribui a outrem o domínio útil do imóvel, pagando a pessoa, que o adquire, e assim se constitui enfiteuta, ao senhorio direto uma pensão, ou foro, anual, certo e invariável."

O enfiteuta é titular do domínio útil, que tem o uso, o gozo e a disposição do bem, podendo, portanto, até alienar seus direitos a terceiros com ou sem o consentimento do proprietário, titular do domínio pleno.

\footnotetext{
${ }^{19}$ A esse respeito José Eduardo Soares de Melo: "Estas figuras (proprietário, titular do domínio útil e possuidor) são consideradas contribuintes na medida em que revelam efetiva capacidade econômica" (MELO, José Eduardo Soares de. Curso de Direito Tributário. 9. ed. São Paulo: Dialética, 2010, p. 548).
} 
O superficiário, nos termos do artigo 1.371 do Código Civil também pode figurar no polo passivo do IPTU: “Art. 1.371. O superficiário responderá pelos encargos e tributos que incidirem sobre o imóvel".

O direito de superfície é um direito real sobre imóvel alheio e está previsto no artigo 1.369 do Código Civil: “Art. 1.369. O proprietário pode conceder a outrem o direito de construir ou de plantar em seu terreno, por tempo determinado, mediante escritura pública devidamente registrada no Cartório de Registro de Imóveis".

O proprietário pode, por escritura pública, outorgar ao superficiário onerosa ou gratuitamente, o direito de utilizar o solo, ou seja, construir ou promover o plantio em determinado terreno que não é de sua propriedade, respeitando os limites legais.

A previsão de pagar o imposto em questão também vem prescrita no artigo $21 \S 3^{\circ}$ do Estatuto das Cidades, Lei 10.257/01. “Art. 21. § 3o O superficiário responderá integralmente pelos encargos e tributos que incidirem sobre a propriedade superficiária, arcando, ainda, proporcionalmente à sua parcela de ocupação efetiva, com os encargos e tributos sobre a área objeto da concessão do direito de superfície, salvo disposição em contrário do contrato respectivo".

O usufrutuário pode figurar no polo passivo do IPTU, como contribuinte eis que titular dos direitos de usar e dispor do bem, sendo detentor da posse podendo administrar, perceber e fruir dos frutos da coisa. Deve zelar pela propriedade como se sua fosse sem alterá-la. O usufruto é um direito real que recai sobre coisa alheia. O artigo 1403, II do Código Civil prescreve: "Art. 1.403 Incumbem ao usufrutuário: II - as prestações e os tributos devidos pela posse ou rendimento da coisa usufruída".

À guisa de esclarecimento algumas decisões a respeito do tema.

Apelação Cível no 70052475290 - Vigésima Segunda Câmara Cível - Comarca de Sapucaia do Sul - Apelante: Município de Sapucaia do Sul - Apelado: Jandira Drumm - Data de Julgamento: 09.01.2013. Ementa: Execução fiscal. IPTU. Legitimidade passiva. Usufrutuário. Redirecionamento. 1. Em caso de usufruto, o sujeito passivo do IPTU é o usufrutuário e não o nu-proprietário do imóvel. Precedentes do STJ. 2. É cabível o redirecionamento da execução contra o usufrutuário, ainda que a certidão de dívida ativa tenha sido expedida em nome do nu-proprietário. Com efeito, os usufrutuários que não comunicaram ao Fisco a transmissão da posse não podem se beneficiar do descumprimento da obrigação acessória. Recurso provido.

RECURSO ESPECIAL. TRIBUTÁRIO. IMPOSTO PREDIAL E TERRITORIAL URBANO. USUFRUTO. LEGITIMIDADE PASSIVA DO USUFRUTUÁRIO. PRECEDENTE DESTE SODALÍCIO. Segundo lição do saudoso mestre Pontes de Miranda, "o direito de usufruto compreende o usar e fruir, ainda que não exerça, e a pretensão a que outrem, inclusive o dono, se o há, do bem, ou do patrimônio, se abstenha de intromissão tal que fira o uso e a fruição exclusivos. É direito, erga omnes, de exclusividade do usar e do fruir". O renomado jurista perlustra, ainda, acerca do dever do usufrutuário de suportar certos encargos, que "os encargos públicos ordinários são os impostos e taxas, que supõem uso e fruto da propriedade, como o imposto territorial e o predial". Na mesma linha de raciocínio, este Superior Tribunal de Justiça, ao apreciar a matéria, assentou que, "em tese, o sujeito passivo do IPTU é o proprietário e não o possuidor, a qualquer título (...) Ocorre que, em certas circunstâncias, a posse tem configuração jurídica de título próprio, de investidura do seu titular como se proprietário fosse. É o caso do usufrutuário que, como todos sabemos, tem a 
obrigação de proteger a coisa como se detivesse o domínio" (REsp 203.098/SP, Rel. Min. Carlos Alberto Menezes Direito, DJ 8.3.2000).

O possuidor a qualquer título, ou seja, aquele que detém a posse do imóvel com vontade de ser dono, isto é, com animus domini. A posse mencionada no dispositivo legal é entendida como exteriorização da propriedade $\mathrm{e}^{20}$.

José Eduardo Soares de $\mathrm{Melo}^{21}$, a esse respeito:

O possuidor é todo aquele que tem de fato o exercício, pleno ou não, de algum dos poderes inerentes à propriedade; o que não ocorre com o detentor, que, achando-se em relação de dependência para com outro, conserva a posse em nome deste e em cumprimento de ordens ou instruções suas (art. 1.198 do Código Civil).

Aires Barreto $^{22}$ sobre o tema:

É bem de ver, no entanto, que a escolha não poderia recair sobre qualquer possuidor. É mister que se trate de posse ad usucapionem, pena de não se lhe poder atribuir a qualidade de contribuinte do imposto (o locatário e o comodatário, por exemplo, não tem posse ad usucapionem). Dito de outro modo, é indispensável que se trate de posse que, por suas características, possa conduzir à propriedade.

Portanto o legítimo possuidor, desde que tenha intenção de ser dono pode ser o contribuinte do imposto em questão, levando-se em conta que é detentor da posse o indivíduo que pode vir a ser proprietário do imóvel, pois esta é tida como exteriorização da propriedade.

O locatário, o arrendatário e o comodatário não podem ser contribuintes do IPTU, pois apesar de estarem na posse do imóvel não são detentores com animus domini. Essa posse não pode ter como consequência o usucapião. Tem apenas a posse provisória do imóvel.

Caso o locatário se responsabilize em Contrato de Locação com o locador pelo IPTU incidente sobre o imóvel só há validade desta obrigação entre as partes.

Não pode o locador, contribuinte do imposto tentar levar a efeitos a cláusula assumida pelo locatário em possível Execução contra a Fazenda Pública Municipal, pois o locatário detém a posse provisória do imóvel, sem o animus domini, pois essa posse não lhe dá o direito de ser proprietário pelo usucapião. O artigo 123 do CTN nos esclarece sobre o tema:

Art. 123. Salvo disposições de lei em contrário, as convenções particulares, relativas à responsabilidade pelo pagamento de tributos, não podem ser opostas à Fazenda Pública, para modificar a definição legal do sujeito passivo das obrigações tributárias correspondentes.

Eis decisão do STJ a respeito:

Ementa (STJ): TRIBUTÁRIO. RECURSO ESPECIAL. IPTU. LOCATÁRIO. ILEGITIMIDADE ATIVA AD CAUSAM. ARTS. 34, 121 E 123 DO CTN. PRECEDENTES. 1. Recurso especial contra acórdão que decidiu pela legitimidade do recorrido, locatário, e condenou o recorrente à restituição dos

\footnotetext{
${ }^{20}$ BALEEIRO, Aliomar. Direito Tributário Brasileiro. 11. ed. Rio de Janeiro: Forense, 2004, p. 246.

${ }^{21}$ MELO, José Eduardo Soares de. Curso de Direito Tributário. 9. ed. São Paulo: Dialética, 2010, p. 548.

${ }^{22}$ BARRETO, Aires F. Imposto Predial e Territorial Urbano - IPTU. In: Ives Gandra da Silva Martins (coord.). Curso de Direito Tributário. 12. ed. São Paulo: Saraiva, 2010, pp. 981/982.
}

Revista de Direito Brasileira | São Paulo, SP | v. 14 | n. 6 | p. 51- 64 | maio/ago. 2016 
valores pagos a título de IPTU, em face da ilegalidade da cobrança. 2. O Superior Tribunal de Justiça possui vastidão de precedentes no sentido de que o locatário é parte ativa ilegítima para impugnar lançamento de IPTU, pois não se enquadra na sujeição passiva como contribuinte e nem como responsável tributário (arts. 121 e 123 do CTN). 3. Contribuinte do imposto é o proprietário do imóvel, o titular do seu domínio útil, ou o seu possuidor a qualquer título (art. 34 do $\mathrm{CTN}$ ). O possuidor a qualquer título refere-se, tão-somente, para situações em que ocorre posse ad usucapionem, não inserida nesta seara a posse indireta exercida pelo locatário. 4. Os documentos de quitação do tributo discutido estão em nome do proprietário. 5. O contrato de locação, com cláusula determinando a responsabilidade do inquilino pela liquidação do IPTU, não pode ser oponível à certidão de pagamento de imposto. 6 . Recurso provido.

Assim, resta claro que a legislação e a jurisprudência pátrias bem delimita os sujeitos passivos em se tratando de contribuição tributária.

\subsubsection{RESPONSÁVEL TRIBUTÁRIO}

O responsável tributário é aquele, que, nos termos do artigo 128 do $\mathrm{CTN}^{23}$, assume, por lei, a responsabilidade pelo pagamento do tributo, embora não tenha realizado o fato previsto na norma. No entanto, esse responsável deve ter uma relação com o fato que fez nascer a obrigação tributária.

A responsabilidade pode ocorrer por solidariedade nas hipóteses em que o imóvel contenha mais de um proprietário. Ressalta-se que no direito tributário a solidariedade não pode ocorrer por contrato. Apenas por lei. A hipótese, nesse caso é aquela prevista no artigo 124, I do CTN. É a solidariedade que ocorre por interesse comum, ou seja, todas as vezes que houver um imóvel com mais de um proprietário. Há ainda a hipótese de responsabilidade por sucessão quando houver venda de imóvel ou de estabelecimento comercial, onde teremos a sucessão intervivos, nos termos do artigo 130 do $\mathrm{CTN}^{24}$.

\subsection{ASPECTO TEMPORAL}

$\mathrm{O}$ aspecto temporal da hipótese de incidência revela de modo implícito ou explícito, a circunstância de tempo importante para o nascimento da obrigação tributária. Nesse caso o aspecto temporal do IPTU é $1^{\circ}$ de janeiro. Caso a lei não tivesse especificado tal data o aspecto temporal iria coincidir com a data da ocorrência do fato imponível, isto é, o momento em que a propriedade fica em nome do proprietário através da escritura registrada.

\subsection{ASPECTO ESPACIAL}

O aspecto espacial da hipótese de incidência do IPTU indica a circunstância de lugar importante para o nascimento do imposto em questão.

O aspecto territorial do IPTU é a zona urbana do Município.

\footnotetext{
23 “Art. 128. Sem prejuízo do disposto neste capítulo, a lei pode atribuir de modo expresso a responsabilidade pelo crédito tributário a terceira pessoa, vinculada ao fato gerador da respectiva obrigação, excluindo a responsabilidade do contribuinte ou atribuindo-a a este em caráter supletivo do cumprimento total ou parcial da referida obrigação".

${ }^{24}$ Art. 130. Os créditos tributários relativos a impostos cujo fato gerador seja a propriedade, o domínio útil ou a posse de bens imóveis, e bem assim os relativos a taxas pela prestação de serviços referentes a tais bens, ou a contribuições de melhoria, subrogam-se na pessoa dos respectivos adquirentes, salvo quando conste do título a prova de sua quitação.
} 


\subsection{ASPECTO MATERIAL}

$\mathrm{O}$ aspecto material da hipótese de incidência é representado por um verbo mais complemento. $\mathrm{O}$ fato que faz nascer a obrigação tributária de pagar o IPTU é ser proprietário, ter o domínio útil ou a posse de bem imóvel por natureza ou por acessão física, como definido na lei civil, localizado na zona urbana do Município.

\subsubsection{BASE DE CÁLCULO}

A base de cálculo ${ }^{25}$ ou base imponível do imposto é o valor venal do imóvel. Esse valor venal corresponde ao valor de venda do imóvel.

\subsubsection{ALÍQUOTA}

A alíquota é o termo do mandamento da norma que aplicado à base de cálculo permite que se chegue ao valor do tributo. Não pode ter feição confiscatória, sob pena de infringir o artigo $150, \mathrm{IV}^{26}$ da CF. Melhor explicando, essa alíquota deve ser instituída por lei da pessoa política tributante e não pode ter base de cálculo ou alíquotas tão altas que obrigue o proprietário do bem aliená-lo para que possa pagar o imposto.

O IPTU, nos termos do artigo $156 \S 1^{\circ}$ incisos I e II da CF terá alíquotas progressivas.

Art. 156. Compete aos Municípios instituir impostos sobre:

I - propriedade predial e territorial urbana;

$\S 1^{\circ}$ Sem prejuízo da progressividade no tempo a que se refere o art. $182, \S 4^{\circ}$, inciso II, o imposto previsto no inciso I poderá: (Redação dada pela Emenda Constitucional $\mathrm{n}^{\mathrm{o}} 29$, de 2000).

I - ser progressivo em razão do valor do imóvel; e (Incluído pela Emenda Constitucional $\mathrm{n}^{\circ} 29$, de 2000).

II - ter alíquotas diferentes de acordo com a localização e o uso do imóvel.

Na progressividade temos bases de cálculo diferentes e alíquotas diferentes. Quanto maior a base de cálculo maior a alíquota.

Alíquotas diferentes possibilita ao legislador a aplicação de alíquotas diversas segundo a aplicação de vários critérios.

Regina Helena Costa a respeito:

A progressividade, por seu turno, implica que a tributação seja mais do que proporcional à riqueza de cada um. Um imposto é progressivo quando a alíquota se eleva à medida que aumenta a base de cálculo. Já a diferenciação significa, exatamente, a adoção de alíquotas diferentes à vista de um ou mais critérios. ${ }^{27}$

\footnotetext{
${ }^{25} \mathrm{O}$ artigo 33 do CTN esclarece qual a base de cálculo do imposto em questão.

"Art. 33. A base do cálculo do imposto é o valor venal do imóvel".

26 “Art. 150. Sem prejuízo de outras garantias asseguradas ao contribuinte, é vedado à União, aos Estados, ao Distrito Federal e aos Municípios:

IV - utilizar tributo com efeito de confisco;"

${ }^{27}$ COSTA, Regina Helena. Curso de Direito Tributário: Constituição e Código Tributário Nacional, $5^{\text {a }}$. ed. São Paulo: Saraiva, 2015, p.236.
} 
O IPTU terá alíquotas progressivas com caráter fiscal, ou seja, para abastecer os cofres públicos, em razão do valor venal do imóvel e poderá ter alíquotas diferentes, de acordo com a localização do imóvel. Nesse caso, temos o caráter extrafiscal, ou seja, aplica-se alíquotas diferentes tendo-se em mira a localização do imóvel, de acordo com o Plano Diretor. Caso a Prefeitura queira que no bairro " $\mathrm{X}$ " tenha apenas indústrias o IPTU terá suas alíquotas exacerbadas para os contribuintes que construírem imóveis residenciais nesse local.

\section{CONCLUSÃO}

O IPTU - Imposto sobre a propriedade predial e territorial urbana é um tributo nãovinculado a uma atividade estatal, classificado como imposto. Tem finalidade fiscal, ou seja, é recolhido para abastecer os cofres públicos a fim de que a pessoa política detentora da competência e da capacidade tributária ativa possa realizar suas atividades em prol do interesse público. Terá finalidade extrafiscal, hipótese em que as alíquotas podem ser variáveis de acordo com a localização e o uso do imóvel.

Tem como fato gerador in concretu ou aspecto material da hipótese de incidência o fato de determinada pessoa física ou jurídica ser proprietária de imóvel localizado na zona urbana de dado Município. No entanto, a definição de propriedade alcança também o domínio útil que se refere ao direito de utilização e disposição do bem de forma ampla e a posse. Não é qualquer posse, mas sim aquela em que o detentor age como se dono fosse, isto é, aquele que tem o animus domini, ou seja, a posse como exteriorização da propriedade. Entendemos que a Constituição adotou, ainda que, implicitamente, uma definição larga de propriedade que alcança o domínio pleno, o domínio útil e a posse ad usucapionem. A Constituição além de garantir o direito de propriedade exige que a propriedade atenda sua função social em prol do interesse público.

\section{REFERÊNCIAS}

ATALIBA, Geraldo. Hipótese de Incidência Tributária. 6.ed. São Paulo: Malheiros, 2004.

BALEEIRO, Aliomar. Direito Tributário Brasileiro. 11. ed. Rio de Janeiro: Forense, 2004.

BARRETO, Aires F. Imposto Predial e Territorial Urbano - IPTU. In: Ives Gandra da Silva Martins (coord.). Curso de Direito Tributário. 12. ed. São Paulo: Saraiva, 2010.

BECHO, Renato Lopes. Lições de Direito Tributário. 3. ed. São Paulo: Saraiva, 2015.

CARRAZZA, Elizabeth Nazar. IPTU e Progressividade, Igualdade e Capacidade Contributiva. 2. ed. São Paulo: QuartierLatin, 2015.

CARRAZZA, Roque Antonio. Curso de Direito Constitucional Tributário. 30. ed. São Paulo: Malheiros Editores, 2015.

CARVAlHO, Paulo de Barros. Curso de Direito Tributário. 27. ed. São Paulo: Saraiva, 2016.

COELHO, Sacha Calmon Navarro. Curso de Direito Tributário Brasileiro. 14. ed. Rio de Janeiro: Forense, 2015. 
COSTA, Regina Helena. Curso de Direito Tributário: Constituição e Código Tributário Nacional. 5. ed. São Paulo: Saraiva, 2015.

DINIZ, Maria Helena. Curso de Direito Civil Brasileiro - Direito das Coisas. Vol. 4. 24. ed. São Paulo: Saraiva, 2009.

FURLAN, Valéria. Imposto Predial e Territorial Urbano. 2. ed. São Paulo: Malheiros Editores, 2004.

GOMES, Orlando. Direitos Reais. 19. ed. Rio de Janeiro: Forense, 2005.

HARADA, Kiyoshi. Direito Financeiro e Tributário. 24. ed. São Paulo: Atlas, 2015.

JUNIOR, Nelson Nery; NERY, Rosa Maria de Andrade. Código Civil Comentado e Legislação Extravagante. 3. ed. São Paulo: Ed. Revista dos Tribunais, 2005.

MACHADO, Hugo de Brito. Curso de Direito Tributário. 31. ed. São Paulo: Malheiros Editores, 2010.

MELO, José Eduardo Soares de. Curso de Direito Tributário. 9. ed. São Paulo: Dialética, 2010. MIRANDA, Jorge. Manual de Direito Constitucional. Tomo IV. 3. ed. Lisboa: Coimbra Editora, 2000.

MONTEIRO, Washington de Barros. Curso de Direito Civil. 19. ed. São Paulo: Saraiva, 1979.

RIZZARDO, Arnaldo. Direito das Coisas. 4. ed. Rio de Janeiro: Forense, 2004.

TARTUCE, Flávio. Direito Civil - Direito das Coisas. Vol. 4. 8. ed. Rio de Janeiro: Forense, 2016. 